\title{
Lignocellulolytic Capability of Endophytic Phyllosticta
}

sp.

Wikee S1, Chumnunti $\mathbf{P}^{2,3}$, Kanghae $A^{2}$, Chukeatirote $\mathrm{E}^{2}$, Lumyong $\mathrm{S}^{1}$ and Faulds $\mathrm{CB}^{4 *}$ ${ }^{1}$ Department of Biology, Faculty of Science, Chiang Mai University, Thailand

${ }^{2}$ School of Science, Mae Fah Luang University, Chiang Rai, Thailand

${ }^{3}$ Institute of Excellence in Fungal Research, School of Science, Mae Fah Luang University, Chiang Rai, Thailand ${ }^{4}$ Aix Marseille Universite', INRA, Biodiversité et Biotechnologie Fongiques (BBF), Marseille, France

*Correspondling author: Faulds CB, Aix Marseille Universite', INRA, Biodiversité et Biotechnologie Fongiques (BBF), Marseille, France

Received: February 16, 2017; Accepted: March 22, 2017; Published: March 28, 2017

\begin{abstract}
The Dothideomycetes represent the largest fungal class of Ascomycota. It is an ubiquitous class of fungi whose members span a wide spectrum of lifestyles and host interactions. The endophytic fungus Phyllosticta is one members of the Dothideomycetes, causing disease in economic crops. Phyllosticta was screened for the degradation of lignocellulosic biomass of commercial relevance, such as rice straw, rice husk, sorghum, wheat straw, miscanthus, lavender flower, and lavender straw. The highest degrading strains were identified from an initial screen and further analyzed for the secretion of lignocellulosic enzymes during growth on the different biomasses. With Phyllosticta capitalensis (MFLUCC14-0233), maximum activity of arabinase $(944.18 \mathrm{U} / \mathrm{ml}$ culture), cellulase $(27.10 \mathrm{U} / \mathrm{ml})$, xylanase $(10.85 \mathrm{U} / \mathrm{ml})$, pectinase $(465.47 \mathrm{U} / \mathrm{ml})$, and laccase $(35.68 \mathrm{U} / \mathrm{ml})$ activities could be detected in the secretome during growth on lavender flowers and lavender straw. Phyllosticta capitalensis is thus an interesting new strain for the production of lignocellulosic enzymes during growth on cheap agro-industrial biomass.
\end{abstract}

Keywords: Agro-industrial residues; Biological pretreatment; Dothideomycetes; Lignocellulosic biomass; Lignocellulytic enzyme; Phyllosticta

\section{Introduction}

The Dothideomycetes represent the largest fungal class within the phylum Ascomycota. It is a ubiquitous class of fungi whose members span a wide spectrum of lifestyles and host interactions [13]. Members of the Dothideomycetes can cause disease in every major crop [4]. Approximately 1,300 genera and 19,000 species have been identified either as endophytes, plant pathogens, or as saprophytes degrading plant biomass, thus threatening agriculture and food security throughout the world [5-8]. In addition to their mode of life, the Dothideomycetes are known for producing secondary metabolites grouped into four main categories based on their biosynthetic origin: polyketides, non-ribosomal peptides, terpenoids and tryptophan derivatives [9]. These secondary metabolites can be both toxic and beneficial to plants and humankind in applications such as agrochemicals, antibiotics, immunosuppressant's, antiparasitics, antioxidants and anticancer agents [10]. New Dothideomycetes are still being discovered worldwide and a large number of these strains remained unexplored regarding their potential use in biotechnology [11-12].

Endophytes provide a broad variety of bioactive secondary metabolites with unique structures and so this class of fungi could be used as potential "nanofactories" producing a range of "green" alternatives to currently employed chemicals [13]. Although the ecological significance of endophytes is not completely clear, it is known that these fungi can exploit dead leaves immediately after their senescence and before they fall from the tree [14], and so could be also exploited for the production of enzymes acting on plant biomass.

A well-known representative of Dothideomycetes fungi in metabolite studies is Phyllosticta (with a Guignardia anamorph). Phyllosticta species are mostly plant pathogens of a broad range of hosts and they are responsible for numerous diseases including leaf spot and black spots to spot on fruits. For example, P. ampelicida species causes black rot disease on grapevines [15], $P$. musarum species causes banana freckle disease [16], $P$. citricarpa is the cause of black spot on citrus and is regarded as a quarantine pest in Europe and the USA [17], and P. capitalensis while non-pathogenic, is found also on citrus usually isolated from black spot lesions and is known as an endophyte on an extensive range of host plants $[6,18]$. P. cartagena and P. ericae have been reported as saprophytes [19].

Phyllosticta spp. are commonly known to produce various kinds of secondary metabolites for example, Phyllosticta derivatives exhibiting growth-inhibitory activity in five cancer cell lines have been isolated from P. cirsii. Phytotoxins, phyllosinol, brefeldin, and PMtoxin are known as fungal pathogenic derivatives from Phyllosticta [20]. Recently, the phytotoxins guignarenones A-F and alaguignardic acid have been isolated which could stimulate the development of herbicides of natural origin [21-23]. In addition, antimicrobial activity active on growth inhibitor of Escherichia coli, Bacillus cereus, and Pseudomonas aeruginosa [24-25]. P. cirsii has been isolated from diseased leaves of Cirsium arvense and it evaluated as a potential biocontrol agent of this noxious perennial weed; furthermore, it produces different phytotoxic metabolites with potential herbicidal activity when grown in liquid cultures [20].

For any fungus which attempts to colonize a higher plant, whether it is endophytic, pathogenic, saprotrophic, biotrophic/necrotrophic, it must contend with the physical barriers of the host. There is a dearth of information however on the cell wall-acting enzymes produced by Phyllosticta sp. to help in the colonization of the leaves when compared to other endophytic and pathogenic fungi, such as Botryosphaeria sp. [26], Colletotrichum sp. [27], Fusarium sp. [28],
J Bacteriol Mycol - Volume 4 Issue 2 - 2017

ISSN : 2471-0172 | www.austinpublishing group.com

Faulds et al. @ All rights are reserved
Citation: Wikee S, Chumnunti P, Kanghae A, Chukeatirote E, Lumyong S and Faulds CB. Lignocellulolytic Capability of Endophytic Phyllosticta sp.. J Bacteriol Mycol. 2017; 4(2): 1047. 
Table 1: Chemical composition of lignocellulosic biomass used as growth substrates.

\begin{tabular}{|c|c|c|c|c|c|c|c|c|c|c|c|}
\hline \multirow{2}{*}{ Substrates } & \multicolumn{8}{|c|}{ Carbohydrate } & \multirow{2}{*}{ lignin } & \multirow{2}{*}{ protein } & \multirow{2}{*}{ fiber } \\
\hline & cellulose & hemicellulose & arabinose & xylose & galactose & mannose & glucose & rhamnose & & & \\
\hline Rice straw [52-53] & 32.5 & 28 & $3.3 \pm 0.2$ & $20.7 \pm 0.2$ & $1.2 \pm 0.2$ & $0.5 \pm 0.2$ & $41.7 \pm 2.2$ & $0.3 \pm 0$ & 19.6 & $7.9 \pm 2.4$ & $20-40$ \\
\hline Rice husk [54-56] & $25-35$ & $18-21$ & 1.7 & 14 & 1.6 & 0.3 & 33.4 & 0.1 & $26-31$ & $2.9-3.6$ & $39-42$ \\
\hline $\begin{array}{l}\text { Wheatstraw [57- } \\
59]\end{array}$ & 38 & 29 & $3.9 \pm 0.2$ & $0.5 \pm 1.1$ & $5.6-10.4$ & $<1$ & $36.3 \pm 1.8$ & 0.3 & 15 & 4 & 32 \\
\hline $\begin{array}{c}\text { Miscanthus [60- } \\
61]\end{array}$ & 43 & 24 & 1.1 & 14.9 & 0.3 & $0-14$ & 38 & $0-1.6$ & 19 & 3 & 6.7 \\
\hline Sorghum [62-63] & $34-44$ & - & - & 24 & & - & 4.9 & - & $18-20$ & 9.7 & 36.6 \\
\hline $\begin{array}{c}\text { Lavander straw } \\
{[64]}\end{array}$ & $43 \pm 1.7$ & $13 \pm 0.9$ & $3.4 \pm 0.1$ & $29 \pm 0.2$ & 3 & 2.5 & 45.6 & 0.9 & $23 \pm 3.6$ & - & - \\
\hline $\begin{array}{c}\text { Lavander flower } \\
{[64]}\end{array}$ & $22.4 \pm 2$ & $12.6 \pm 2$ & 7.3 & $17.9 \pm 0.1$ & $6.2 \pm 0.2$ & $3 \pm 0.1$ & $36.2 \pm 0.4$ & 1.2 & $23.6 \pm 2.6$ & 6.3 & 8.9 \\
\hline
\end{tabular}

Table 2: Radial growth rate of the fungal strains cultivated in different biomass substrates.

\begin{tabular}{|c|c|c|c|c|c|c|c|c|c|}
\hline \multirow{2}{*}{ Fungal strains (MFLUCC) } & \multicolumn{4}{|c|}{ Radial growth rate (cm/day) } \\
\cline { 2 - 8 } & Miscanthus & Rice husk & Rice straw & Sorghum & Wheat Straw & Lavender flower & Lavender straw & Glucose \\
\hline $10-0137$ & 0.06 & 0.05 & 0.04 & 0.17 & 0.05 & 0.06 \\
\hline $12-0015$ & 0.34 & 0.36 & 0.24 & 0.27 & 0.22 & 0.06 \\
\hline $12-0232$ & 0.34 & 0.33 & 0.31 & 0.29 & 0.23 & 0.31 \\
\hline $14-0233$ & 0.34 & 0.33 & 0.31 & 0.24 & 0.21 & 0.33 & 0.27 \\
\hline
\end{tabular}

Macrophomina phaseolina [29], Magnaporthe sp. [30-31], smut fungi, such as Sporisorium scitamineum [32] and Ustilago maydis [33], and Stagonospora nodorum [34].

In this study, we examined the production of ligninolytic enzymes on seven previously characterized lignocellulosic agro-industrial residues by four Phyllosticta sp.: the pathogenic P. citrimaxima and three strains of the non-pathogenic endophyte $P$. capitalensis.

\section{Materials and Methods}

\section{Collection of fungal cultures}

Fungal cultures were obtained from Mae Fah Luang University Culture Collection (MFLUCC): the pathogen strains Phyllosticta citrimaxima MFLUCC10-0137 was isolated from Citrus maxima, $P$. capitalensis MFLUCC12-0015 and MFLUCC12-0232 were isolated from Euphorbia milii and Philodendron X 'Xanadu', respectively. An endophyte strain P. capitalensis MFLUCC14-0233 was isolated from Hevea brasiliensis [7]. Wheat straw and miscanthus were obtained from Vivescia (Reims, France), dried, and chopped $(\approx 4 \mathrm{~mm})$. Lavender straw and flowers were obtained as the residues after steam distillation from la société Bontoux SA (Saint Aubansurl'Ouveze, Drôme, France). They were collected at the beginning of September 2013, air dried for 12 days, flowers and straw separated then the fractions knife milled. Rice straw, husks and sorghum were obtained from rice cultivation fields (Phan, Thailand).

\section{Growth measurement}

Four strains of Phyllosticta were monitored on agar plates containing $15 \mathrm{mg} / \mathrm{ml}$ biomass for 20 days in the different biomass media as follow; lavender flower (LF), lavender straw (LS), miscanthus (MC), rice straw (RS), rice husk (RH), sorghum (SG), wheat straw (WS). Growth was established by measuring the diameter of the growing edge of the mycelium with time. The growth measurement was recorded at day $3,5,7,14$, and day 20 .

\section{Preparation of fungal supernatant for enzyme essays}

Growth condition in Liquid State Fermentation (LSF): The cultures were grown over 10 days in the presence of the seven biomasses in liquid medium $(20 \mathrm{~g} / \mathrm{L})$, and stored at $30^{\circ} \mathrm{C} 130 \mathrm{rpm}$. The culture supernatants from all treatments were collected on days $0,3,7,10$, and 12 of incubation and stored at $-20^{\circ} \mathrm{C}$ until use. The culture supernatants were then concentrated by filtration using a 0.2 micron-pore-size (polyethersulfone membrane; Vivaspin; Sartorius, Germany), diafiltered, and concentrated (Vivaspin polyethersulfone membrane with a $10-\mathrm{kDa}$ cutoff; Sartorius) in $50 \mathrm{mM}$ acetate solution buffer, $\mathrm{pH} 5$, and stored at $-20^{\circ} \mathrm{C}$ until use [35].

\section{Enzyme activities}

The culture supernatants produced by the four Phyllosticta strains on different lignocellulosic substrates were assayed to determine the enzyme activities present. All chemicals were of the highest purity grade available and were purchased from Sigma-Aldrich (Saint-QuentinFallavier, France) if not stated otherwise. Cellulose degradation was assessed by the quantification of endo-1,4- $\beta$-D-glucanase (AzoCM-Cellulose) (Megazyme, Ireland) and $\beta$-glucosidase (pNP- $\beta$-Dglucopyranoside [pGlu]) activities. Hemicellulose degradation was determined by quantifying the activity of endo- $1,4-\beta$-D-Xylanase on azo-birchwoodxylan (Megazyme, Ireland), acetyl esterase on pNPacetate (pAc), and arabinose was assessed with $1 \%$ arabinogalactan $[35,36]$. Oxidative enzymes were assayed with ABTS (2,2'-azinobis (3-ethylbenzthiazoline-6-sulfonic acid) [37] as a substrate for laccase activity, Manganese Peroxidase (MnP) by the oxidation of $\mathrm{MnSO}_{4}$ [38], and Lignin Peroxidase ( $\mathrm{LiP}$ ) was assayed using veratryl alcohol as substrate in the presence of $\mathrm{H}_{2} \mathrm{O}_{2}$ [39]. Pectinase activity was estimated by using apple pectin and citrus pectin [40]. The total amount of protein present in the culture supernatant was estimated using the Bradford assay with a BSA (Bovine serum albumin) standard curve [41]. Total reducing sugars were quantified using dinitrosalicylic acid method (DNS) [42]. All essays were performed in triplicate. 


\section{Results and Discussions}

\section{Growth profiles on the different lignocellulosic biomass}

In this study, we focused on lignocellulosic residues from agroagriculture in Thailand and France such as lavender flower, lavender straw, miscanthus, rice straw, rice husk, sorghum, and wheat straw. Their chemical composition is shown in Table1. Growth of the four pure Phyllosticta strains was monitored on agar plates containing $15 \mathrm{mg} / \mathrm{ml}$ biomass for 20 days. Growth was established by measuring the diameter of the growing edge of the mycelium over time (Table 2).

Colonies of the phytopathogen P. citrimaxima (MFLUCC 100137) were flat, initially white with abundant mycelium, gradually becoming greenish to dark green after 2-3 days growth, with white hyphae at the margin, eventually turning black. Very slow growing ( $\bar{X}=0.1 \mathrm{~cm} /$ day $)$ in all treatments except sorghum $(\bar{X}=0.2 \mathrm{~cm} /$ day $)$. Between days 3-7, Phyllosticta citrimaxima was fast growing on all substrates, stabilizing after 7 days, except for growth on sorghum, where the diameter of growth reached $4.25 \mathrm{~cm}$ after 20 days. The colonies of all the endophyte P.capitalensis were flat, initially greenish to dark green after 2-3 days, eventually turning black. Fast growing (between $=0.3$ and $0.35 \mathrm{~cm} /$ day) on all substrates, with diameter of growth of $P$. capitalensis MFLUCC12-015 reaching $8.0 \mathrm{~cm}$ on rice husk on day 14. On day 3-7, P.capitalensis MFLUCC12-015 was fast growing in every growth conditions at day 2-10, but the growths were stable after 10 days. Between day 5-7, P. capitalensis MFLUCC12-0232
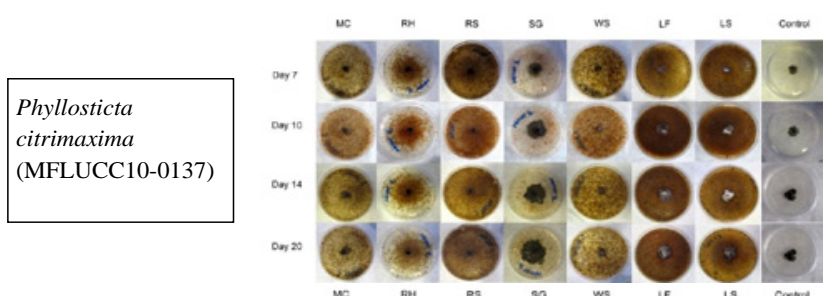

Phyllosticta capitalensis (MFLUCC12-0015)
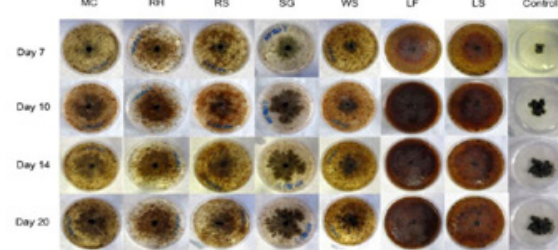

Phyllosticta

capitalensis

(MFLUCC12-0232)

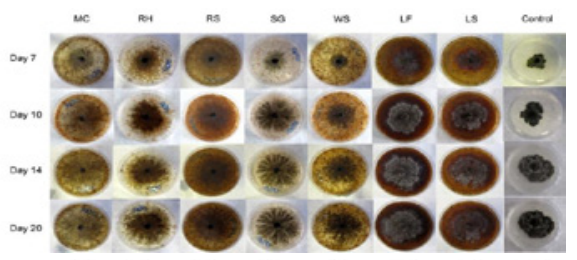

Phyllosticta

capitalensis

(MFLUCC14-0233)

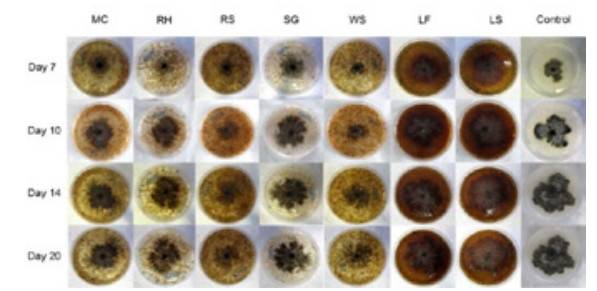

Figure 1: Growth of the four Phyllosticta sp. on different biomass mass media $(15 \% \mathrm{w} / \mathrm{w})$.

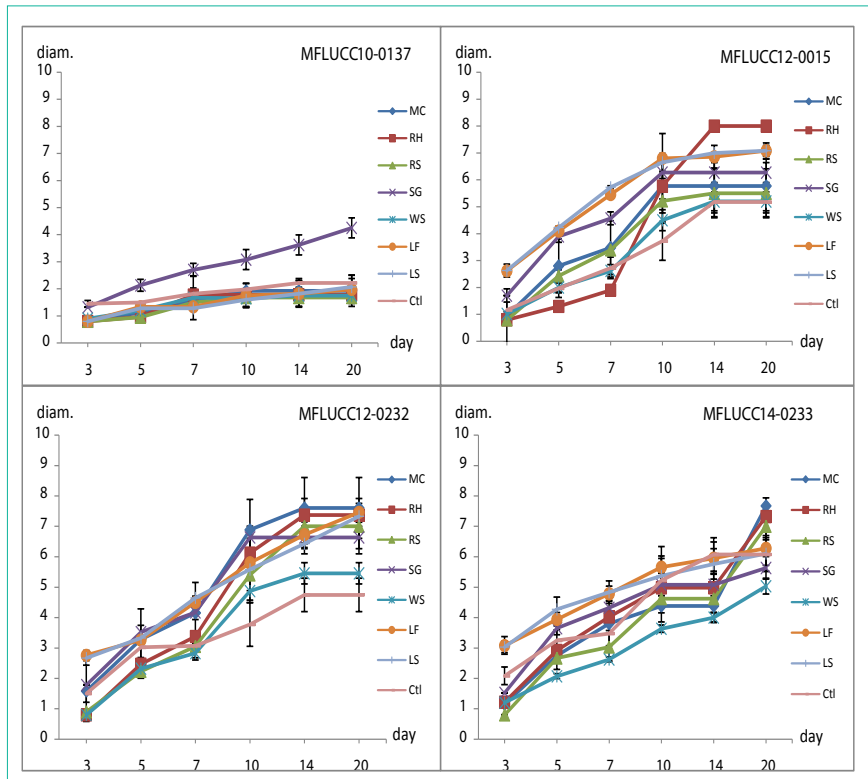

Figure 2: Radial growth rate of the fungal strains cultivated on different biomasses substrates (a) Phyllosticta citrimaxima (MFLUCC10-0137); (b) Phyllosticta capitalensis (MFLUCC12-0015); (c) Phyllosticta capitalensis (MFLUCC12-0232); and (d) Phyllosticta capitalensis (MFLUCC 14-0233) on biomass mass media.

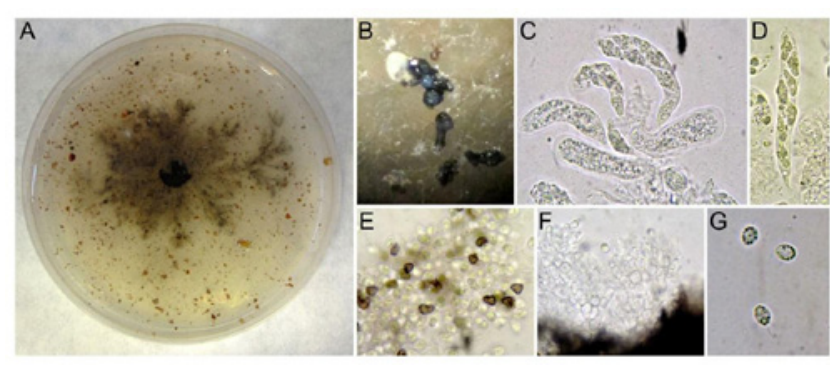

Figure 3: Represent characteristics of Phyllosticta capitalensis (MFLUCC14-0233) on sorghum media agar. A. Colony on Sorghum media agar B. Production of spore on media C-D. Sexual stage (Guignardia) E. Appressoria and germ tube F. Conidiophores G. Conidia with apical appendage (asexual stage).

started to producing conidia on sorghum biomass agar. P. capitalensis (MFLUCC 14-0233), start producing conidia on sorghum biomass agar and pycnidia could be observed on biomass residue after day 5-7 of growth (Figure 1).

The rate of growth on lavender flowers and straw was initially faster for all species, except for $P$. citrimaxima MFLUCC10-0137, especially over the first 6 days. At day 3, the growing edge of $P$. capitalensis MFLUCC12-015 mycelium reached almost $3 \mathrm{~cm}$, compared to growth on the other substrates, where it reached only 0.8-1.8 cm over the same time period (Figure 2). Growth tended to stabilize after 10 days. On lavender flower and lavender stem biomass agar, the agar at the margin of the leading edge of most fungal strains changed to a red color during 1-3 days of incubation and turn darker after 7-20 days, except for P. citrimaxima. Most of strains could produce pycnidia and conidia on biomass residue (Figure 3 ) except for P. citrimaxima. Essential oils from plants, such as lavender, oregano, sage and mint are generally conceived as inhibitory to fungal 


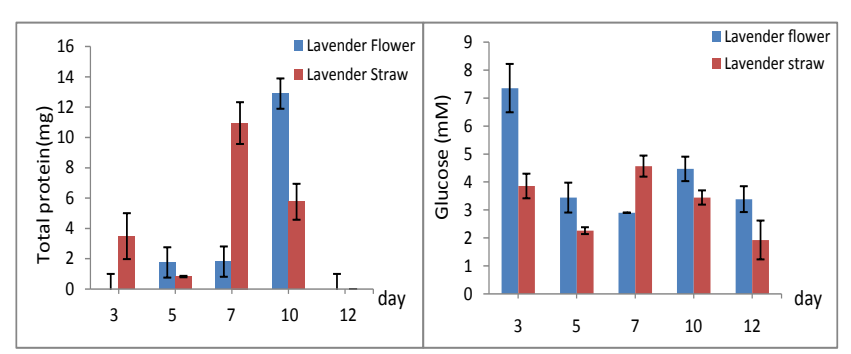

Figure 4: Total protein concentration (a) and total reducing sugars (b) in the culture supernatants of MFLUCC14-0233 over a 12 days period.

Table 3: Enzyme activities were detected after recovered extracts and concentrated through a $10 \mathrm{kD}$ membrane.

\begin{tabular}{|c|c|c|c|c|}
\hline \multirow{2}{*}{ Enzyme } & \multicolumn{2}{|c|}{ Lavender flower } & \multicolumn{2}{c|}{ Lavender straw } \\
\cline { 2 - 5 } & $\begin{array}{c}\text { protein } \\
\text { (total } \mathbf{~ m g )}\end{array}$ & $\begin{array}{c}\text { Activity } \\
\text { (U/mg) }\end{array}$ & $\begin{array}{c}\text { protein } \\
\text { (total } \mathbf{~ m g )}\end{array}$ & $\begin{array}{c}\text { Activity } \\
\text { (U/mg) }\end{array}$ \\
\hline Arabinase & 1.8 & 53,287 & 3.5 & 45,211 \\
\hline Cellulase & 1.8 & 2,710 & 3.5 & 1,144 \\
\hline Laccase & 1.8 & 336 & 5.8 & 1,189 \\
\hline Pectinase & 1.8 & 13,238 & 11.0 & 31,731 \\
\hline Xylanase & 1.8 & 955 & 3.5 & 362 \\
\hline
\end{tabular}

growth [43]. This result suggests that in the residual biomass after oil extraction may contain compound(s) which are stimulatory to growth and thus opens the possibility of using lavender by-products for biomass treatment processes within a bio refinery concept.

Growth profiles are thought to identify differences between fungal species and strains which could be correlated to their genetic enzyme compliments and expression patterns. While two Dothideomycetes with different life styles show differences during growth on Dothistroma minimal media, C. fulvus and D. septosporum showed similar growth on simple sugars $(25 \mathrm{mM})$, birchwood xylan, apple pectin and lignin $(1 \% \mathrm{w} / \mathrm{v})$ over $2-4$ weeks, although the later grew slightly better on pectin, contradictory to its lower pectinolytic gene number but supported by the number of pectinolytic enzymes expressed during growth on their respective natural plant hosts [44]. This suggests that the expression regulation of gene involved in plant deconstruction is a more dominant factor than the number of the lignocellulosic genes in the genomes.

\section{Enzyme activities of the Phyllosticta sp. during growth on the lignocellulosic biomass}

The culture supernatants produced during growth of the four Phyllosticta strains on the 7 lignocellulosic residues were assayed to determine lignocellulose-degrading enzyme activities as well as the total amount of protein and total reducing sugars released into the media. All fungal supernatant from lavender media showed high amount of total protein; however, the activity levels were very low. All reducing sugar appeared to be consumed at the end of cultivation of P.capitalensis MFLUCC12-0015 and MFLUCC12-0232 while the level of reducing sugars increased during 5-7 days of cultivation of $P$. citrimaxima MFLUCC10-0137 and P. capitalensis MFLUCC14-0233. No cellulase, xylanase, peroxidase, esterase or arabinofuranosidase activity could be detected. Either the fungi do not produce these enzymes or the levels are too dilute in the sample extracts for detection, even after concentration.
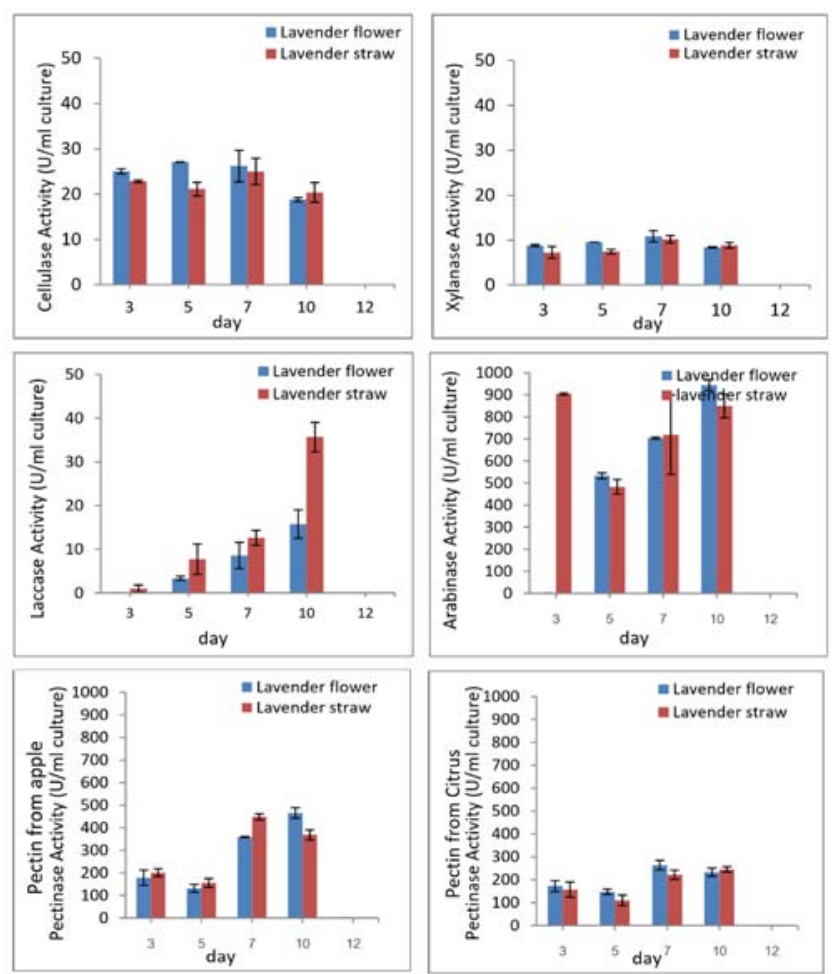

Figure 5: The production of (a) cellulase and (b) Xylanase (c) Laccase (d) Arabinase activities produced by Phyllosticta capitalensis MFLUCC14-0233 in lavender culture medium; The production of (e) Pectinase activity against apple pectin; (f) Pectinase activity against citrus pectin by $P$. capitalensis during 12 days of incubation.

\section{P. capitalensis MFLUCC14-0233 growths}

Due to the more rapid growth of $P$. capitalensis MFLUCC14-0233, the fungus was chosen to be cultured on Lavender Flower Medium (LFM), Lavender Straw Medium (LSM), Wheat Straw Medium (WSM) and potato Dextrose Broth (PDB). During the days of incubation, extracellular protein from LFM was determined to be $1.76 \pm 0.75 \mathrm{mg}, 1.81 \pm 0.23 \mathrm{mg}$, and $12.89 \pm 1.35 \mathrm{mg}$ at days 5,7 and 10 , respectively, while extracellular protein on LSM was determined to be $3.49 \pm 1.51 \mathrm{mg}$ protein, $0.83 \pm 0.05 \mathrm{mg}$ protein, $10.95 \pm 1.38 \mathrm{mg}$ protein, and $5.76 \pm 1.19 \mathrm{mg}$ protein at day $3,5,7$, and 10 , respectively. Extracellular protein was no longer detected at day 12. Additionally, extracellular protein in the supernatants from WSM and PDB grown cultures could also not be detected. A small amount of protein was detected in the supernatant of LSM at day 3, dropping by day 5 and reaching the highest concentration on day 7 . On the other hand, protein in LFM could not be detected at day 3, increasing after day 5 and 7 then reached maximum protein concentration at day 10. Protein levels rapidly decreased to zero at day 12 during growth on both lavender media. Reducing sugar release, as glucose equivalents, was monitored at day $3,5,7,10$, and 12 . The highest concentration of reducing sugar could be detected on day 3 for LFM $(7.36 \pm 0.86 \mathrm{mM})$ and rapidly decreased after two days. The sugar concentration in the culture supernatant from LSM at day 3 was $3.86 \pm 0.44 \mathrm{mM}$, dropping to $1.93 \pm 0.69 \mathrm{mM}$ at day 12. P.capitalensis cultured on LSM and LFM for 12 days and selected enzyme activities were determined. 


\section{Pectinolytic activity}

The maximum production of arabinasein LSM occurred after 3 days of incubation $(904.22 \mathrm{U} / \mathrm{ml})$ while arabinose activity in LFM could not be detected. However, the maximun activity of arabinase produced during growth on LFM was $944.18 \mathrm{U} / \mathrm{ml}$ at day 10 . Pectinase activity in concentrated extracellular supernatant of $P$. capitalensis in LFM showed a maximum activity against apple pectin of 448.39 $\mathrm{U} / \mathrm{ml}$ at day 7 and $465.47 \mathrm{U} / \mathrm{ml}$ at day 10 . In comparison, activity against citrus pectin was lower, with the highest activity at day 7 in LFM $(263.37 \mathrm{U} / \mathrm{ml})$ then at day 10 for LSM (245.11 U/ml) (Figure 5).

\section{Cellulolytic and xylanolytic activity}

The highest of cellulase activity $(27.10 \mathrm{U} / \mathrm{ml})$ and xylanase activity $(10.85 \mathrm{U} / \mathrm{ml})$ could be observed in cultures grown in LFM at day 5 and 7, respectively. According to the result, cellulase activity on LFM or LSM were not significant different from day 3 to 10 the activity range between 20-27 U/ml, especially, xylanase activity during cultivation time could be detected at approximately 7-10 U/ml. Due to the low number of cellulolytic and hemi cellulolytic CAZymes (GH6, GH7, GH10, GH11, GH45, GH61, CE1, CE3 and CBM1) present in the Capnodiales order of Dothideomycetes compared to the Hysteriales and Pleosporales order, it has been suggested that the Capnodiales (sooty molds) do not extensively degrade cellulose or that they employ another strategy for degradation [4]. Phyllosticta/Guignardia sp. belongs to the Botryosphaeriaceae order of the Pleosporomycetidae. The causal agent of citrus black spot, G. citricarpa, produced significantly more amylase, endoglucanase, polygalacturonase, pectin methyl esterase and pectin lyase compared to the endophytic G. mangiferae (anamorph P. capitalensis), which suggests that these enzymes, especially pectinolytic ones, could be key in the development of the disease as they are usually the first extracellular enzymes produced during infection [45].

\section{Laccase and peroxidase activity}

To confirm the presence of laccase, the laccase activity in the supernatant of $P$. capitalensis grown on lavender flower or lavender straw were assayed using 2,2'-azino-bis-3-ethylbenzthiazoline6-sulphonic acid (ABTS) as substrate. The results show that the maximum laccase activity from P. capitalensis in LSM at day 10 was $35.68 \mathrm{U} / \mathrm{ml}$ (Figure 5). Furthermore, no lignin peroxidase and manganese peroxidase activity was detected in the culture supernatants. This indicates that these strains possibly have different mechanisms to utilize the plant biomass as a carbon source during growth.

A co-localized block of genes, including oxidoreductases, is conserved in most members of the Dothideomycetes class, and upregulated during pathogenicity, although differentDothideomycetes have different strategies for growth on their plant substrates [4]. A laccase from the hemibiotrophic fungus Colletotrichum orbicular has been shown to be involved in the production of mycelial melanin during plant infection [46]. This laccase had close homologues in $C$. higginsianum and C. graminicola, and different from the Magnaporthe oryzae laccase. Dothideomycetes have a high number of conserved nonribosomal peptides synthesases which resemble those proteins responsible for siderophore biosynthesis and intracellular iron storage. This later role is important for cellular function as it prevents Fenton reactions from occurring and the concomitant accumulation of reactive oxygen species. Schizophyllum commune, a member of the order Agaricales, lacks the genes encoding lignin-acting peroxidases [4], suggesting that it degrades lignin using alternative methods, possibly using the laccases identified in the genome [47]. Laccases, however, are absent from the white-rot basidiomycete Phanerochaete chrysosporium, a member of the order Polyporales [48], indicating that fungi employ a vast diversity of mechanisms to breakdown lignin and related compounds.

Two Dothideomycetes species which are phylogenetically close but have different lifestyles and hosts have recently had their genomes sequenced [44]. Cladosporium fulvum is a biotrophic infecting tomato while Dothistroma septosporum is a hemibiotrophic infecting pine. Both fungi colonize their host through germinating conidia on the leaf surface producing hyphae which enter the leaf through the stomata and colonizing the apoplastic space between the mesophyll cells. Their difference in lifestyle has led to the evolution of divergent sets of genes, but with conserved genes showing their common ancestry. C. fulvum, which is used as a model system for plant-microbe interaction as it causes leaf mold, has the genomic set of carbohydratedegrading enzymes, including a large pectinolytic arsenal, but many of these genes are not expressed in planta. In contrast, Botrytis cinera, a necrotrophic pathogen of tomato, produces a high pectinolytic activity during the invasion of the soft pectin-rich plant tissues [49]. Thus, instead of degrading the plant cell wall, C. flavus is thought to facilitate the local modification of the middle laemella and primary cell walls to allow better penetration of the hyphae into these pectinrich areas, similar to that described for the forest root colonizing ectomycorrhizal, such as Laccaria bicolor [50].

It is not necessarily true that the enzymes secreted by the Phyllosticta strains are involved in plant cell wall breakdown, but could be secreted in order to remodel the plant tissue and fungal wall to facilitate growth and to fend off competitors (fungal and bacterial),as in the case with the ectomycorrhizal Laccaria bicolor where a reduced repertoire of carbohydrate-acting enzymes remains, but this is sufficient to aid the fungal hyphae penetrate between the root cells by loosening contact between the epidermal cells [51]. Whenever the genome of these pathologically relevant Phyllosticta sp. are sequenced, this will enable us to compare these biochemical assays to annotated CAZymes and to begin to understand the mechanism in which Phyllosticta, and in particular P. capitalensis, employ to degrade plant biomass.

\section{Conclusions}

Phyllosticta produce low levels of lignocellulolytic enzyme during cultivation on agro-industrial residues. While the fungi grow well on these carbon sources, especially those derived from the lavender oil industry, there is low production of key degradative enzymes. Further genomic and proteomic analysis is required to determine the manner in which this group of fungi utilize plant biomass for growth.

\section{Acknowledgement}

This work was supported by the Franco-Thai PHC Program (Project Code: $31824 \mathrm{~W}$ ) which gives an opportunity for scientific cooperation between Thai and France scientists. We thanks Laurence Lesage-Meessen (INRA-BBF) for providing the lavender substrates used in this experiment. 


\section{References}

1. Kirk PM, Cannon PF, Minter DW, Stalpers JA. Dictionary of the Fungi CABI. Wallingford, UK. 2008.

2. Schoch CL, Crous PW, Groenewald JZ, Boehm EWA, Burgess TI, de Gruyte $\mathrm{J}$, et al. A class-wide phylogenetic assessment of Dothideomycetes. Stud Mycol. 2009; 64: 1-15.

3. Hyde KD, Jones EG, Liu JK, Ariyawansa H, Boehm E, Boonmee S, et al. Families of Dothideomycetes. Fungal Diversity. 2013; 63: 1-313.

4. Ohm RA, Feau N, Henrissat B, Schoch CL, Horwitz BA, Bradshaw RE, et al. Diverse lifestyles and strategies of plant pathogenesis encoded in the genomes of eighteen Dothideomycetes fungi. In Book of Abstracts $27^{\text {th }}$ Fungal Genetics Conference. Asilomar, Pacific Grove, California, USA. 2013 12.

5. Wikee S, Udayanga D, Crous PW, Chukeatirote E, McKenzie EH, Bahkali $\mathrm{AH}$, et al. Phyllosticta-an overview of current status of species recognition. Fungal Diversity. 2011; 51: 43-61.

6. Wikee S, Lombard L, Crous PW, Nakashima C, Motohashi K., Alias SA, et al. Phyllosticta capitalensis, a widespread endophyte of plants. Fungal Div. 2013; 60; 91-105.

7. Wikee S, Lombard L, Nakashima C, Motohashi K, Chukeatirote E Cheewangkoon R, et al. A phylogenic re-evaluation of Phyllosticta (Botryosphaeriales). Studies in Mycology. 2013; 76; 1-29.

8. Manamgoda DS, Cai L, McKenzie EH, Crous PW, Madrid H, Chukeatirote $\mathrm{E}$, et al. A phylogenetic and taxonomic re-evaluation of the BipolarisCochliobolus-Curvularia complex. Fungal Diversity. 2012; 56: 131-144.

9. Muria-Gonzalez MJ, Chooi Y-H, Breen S, Solomon PS. The past, present and future of secondary metabolite research in the Dothideomycetes. Mol. Plan Path. 2015; 16; 92-107

10. Strobel GA. Endophytes: a rich source of bioactive products. Microb. Infect. 2003; 5; 535-544.

11. Verkley GJ, Crous PW, Groenewald JE, Braun U, Aptroot A. Mycosphaerella punctiformis revisited: morphology, phylogeny, and epitypification of the type species of the genus Mycosphaerella(Dothideales, Ascomycota). Mycological research. 2004; 108: 1271-1282.

12. Damm U, Verkley GJ, Crous PW, Fourie PH, Haegi A, Riccioni L. Nove Paraconiothyrium species on stone fruit trees and other woody hosts. Persoonia-Molecular Phylogeny and Evolution of Fungi. 2008; 20: 9-17.

13. Sunkar S, Nachiyar V. Endophytes as potential nanofactories. Int J Chem, Environ Biological Sci. 2013; 1: 488-491.

14. Zifcakova L, Dobiasova P, Kolarova Z, Koukol O, Baldrian P. Enzyme activities of fungi associated with Piceaabies needles. Fungal Ecol. 2011 4; 427-436.

15. Wicht B, Petrini O, Jermini M, Gessler C, Broggini GA. Molecular, proteomic and morphological characterization of the ascomycete Guignardia bidwellii agent of grape black rot: a polyphasic approach to fungal identification. Mycologia. 2012; 104: 1036-1045

16. Wong MH, Crous PW, Henderson J, Groenewald JZ, Drenth A. Phyllosticta species associated with freckle disease of banana. Fungal Divers. 2012; 56 173-187.

17. Stammler G, Schutte GC, Speakman J, Miessner S, Crous PW. Phyllosticta species on citrus: Risk estimation of resistance to Qol fungicides and identification of species with cytochrome b gene sequences. Crop Protection. 2013; 48: 6-12.

18. Zavala MGM, Er HL, Goss EM, Wang NY, Dewdney M, van Bruggen AHC. Genetic variation among Phyllosticta strains isolated from citrus in Florida that are pathogenic or nonpathogenic to citrus. Trop. Plant Path. 2014; 39 $119-128$.

19. Van Der Aa VHS, Aptroot A, Summerbell R, Verkley G. A revision of the species described in Phyllosticta. Utrecht: Centraalbureauvo or Schimmelcultures. 2002
20. Evidente A, Cimmino A, Andolfi A, Vurro M, Zonno MC, Cantrell CL, Motta A Phyllostictines A-D, oxazatricycloalkenones produced by Phyllostictacirsii, a potential mycoherbicide for Cirsium arvense biocontrol. Tetrahedron. 2008; 64: 1612-1619.

21. Molitor D, Liermann JC, Berkelmann-Löhnertz B, Buckel I, Opatz T, Thines E. Phenguignardic acid and guignardic acid, phytotoxic secondary metabolites from Guignardia bidwellii. J. Natr. Products. 2012; 75; 1265-1269.

22. Sommart U, Rukachaisirkul V, Trisuwan K, Tadpetch K, Phongpaichit S Preedanon S, et al. Tricycloalternarene derivatives from the endophytic fungus Guignardia bidwellii PSU-G11. Phytochem. Letts. 2012; 5; 139-143.

23. Buckel I, Molitor D, Liermann JC, Sandjo LP, Berkelmann-Löhnertz B, Opatz $\mathrm{T}$, et al. Phytotoxicdioolanone-type secondary metabolites from Guignardia bidwellii. Phytochem. 2013; 89; 96-103.

24. Wikee S, Jaidee P, Wongkam S, Mckenzie EHC, Hyde KD, Chukeatirote E. Antimicrobial activity of crude extracts of Phyllosticta spp. Mycology 2013; $4 ; 112-117$

25. Chukeatirote E, Wikee S, Hyde KD. Diversity and antibacterial activity of Phyllosticta species. MicologíaAplicada International. 2015; 27: 1-9.

26. Esteves AC, Saraiva M, Correia A, Alves A. Botryosphaeriales fungi produce extracelular enzymes with biotechnological potential. Can. J. Microbiol. 2014; $60 ; 332-342$

27. O'Connell RJ, Thon MR, Hacquard S, Amyitte SG, Kleemann J, et al. Lifestyle transitions in plant pathogenic Colletotrichum fungi deciphered by genome and transcriptome analyses. Nature Genet. 2012; 44: 1060-1067.

28. Zhao Z, Liu H, Wang C, Xu JR. Comparative analysis of fungal genomes reveals different plant cell wall degrading capacity in fungi. BMC genomics. 2013; 14

29. Islam MS, Haque MS, Islam MM, Emdad EM, Halim A, Hossen QM, et al. Tools to kill: genome of one of the most destructive plant pathogenic fung Macrophomina phaseolina. Bmc Genomics. 2012; 13.

30. Dean RA, Talbot NJ, Ebbole DJ, Farman ML, Mitchell TK, Orbach MJ, et al. The genome sequence of the rice blast fungus Magnaporthe grisea. Nature 2005; 434; 980-986.

31. Pham KTM, Nguyen HH, Murai T, Chuma I, Tosa Y, Nakayashiki H. Histone $\mathrm{H}_{3} \mathrm{~K}_{4}$ methyltransferases globally regulates substrate-dependent activation of cell-wall-degrading enzymes in Magnaporthe oryzae. J. Gen. Plant Pathol. $2015 ; 81 ; 127-1230$.

32. Taniguti LM, Schaker PDC, Benevenuto J, Peters LP, Carvalho G, Palhares $\mathrm{A}$, et al. Complete genome sequence of Sporisorium scitamineum and biotrophic interaction transcriptome with sugarcane. PLOS One 2015; 10; e0129318.

33. Couturier M, Navarro D, Olive C, Chevret D, Haon M, Favel A, et al. Postgenomic analysis of fungal lignocellulosic biomass degradation reveal the unexpected potential of the plant pathogen Ustilago maydis. BMC Genomics 2012; 13; 57

34. Hane JK, Lowe RGT, Solomon PS, Tan K-C, Schoch CL, Spatafora JW, et al. Dothideomycete plant interactions illuminated by genome sequencing and EST analysis of the wheat pathogen Stagonospora nodorum. Plant Cell. 2007; 19: 3347-3368.

35. Berrin JG, Navarro D, Couturier M, Olivé C, Grisel S, Haon M, et al. Exploring natural fungal biodiversity from tropical and temperate forests to improve biomass conversion. Applied and environmental microbiology. 2012

36. Faulds CB, Pérez-Boada M, Martínez ÁT. Influence of organic co-solvents on the activity and substrate specificity of feruloyl esterases. Bioresource technology. 2011; 102: 4962-4967.

37. Herpoël I, Moukha S, Lesage-Meessen L, Sigoillot JC, Asther M. Selection of Pycnoporu scinnabarinus strains for laccase production. FEMS Microbiology Letters. 2000; 183: 301-306.

38. Husaini A, Fisol FA, Yun LC, Hussain MH, Roslan HA. Lignocellulolytic enzymes produced by tropical white rot fungi during biopulping of Acacia mangium wood chips. J Biochem Technol. 2011; 3: 245-250. 
39. Tien M, Kirk TK. Lignin-degrading enzyme from Phanerochaete chrysosporium: purification, characterization, and catalytic properties of a unique $\mathrm{H}_{2} \mathrm{O}_{2}$-requiring oxygenase. Proceedings of the National Academy of Sciences. 1984; 81: 2280-2284.

40. Suresh B, Viruthagiri T. Optimization and kinectics of pectinase enzyme using Aspergillu sniger by solid-state fermentation. Indian Journal of Science and Technology. 2010; 3: 867-870.

41. Kruger NJ. The Bradford method for protein quantitation. Basic protein and peptide protocols. 1994: 9-15.

42. Miller GL. Use of dinitrosalicylic acid reagent for determination of reducing sugar, Anal. Chem. 1959; 31: 426-428.

43. Kadoglidou K, Lagopodi A, Karamanoli K, Vokou D, Bardas GA, Menexes $G$, et al. Inhibitory and stimulatory effects of essential oils and individua monoterpenoids on growth and sporulation of four soil-borne fungal isolates of Aspergillus terreus, Fusarium oxysporum, Penicillium expansum, and Verticillium dahliae. European journal of plant pathology. 2011; 130: 297-309.

44. De Wit PJGM, van der Burgt A, Okmen B, Stergiopoulos I, Abd-Elsalam KA Aerts $\mathrm{AL}$, et al. The genomes of the fungal plant pathogens Cladosporium fulvum and Dothistroma septosporum reveal adaption to different hosts and lifestyles but also signatures of common ancestry. PLOS One 2012; 8

45. Romao AS, Sposito MB, Andreote FD, Azevedo JL, Araujo WL. Enzymatic differences between endophyte Guignardia mangiferae (Botryosphaeriaceae) and the citrus pathogen G. citricarpa. Genet. Mol. Res. 2011; 10; 243-252.

46. Lin SY, Okuda S, Ikeda K, Okuno T, Takano Y. LAC2 encoding a secreted laccase is involved in appressorialmelanization and conidial pigmentation in Colletotrichum orbiculare. Mol. Plant-Microbe Int. 2012; 25; 1552-1561.

47. Ohm R, Riley R, Salamov A, Min B, Choi I-G, Grigoriev IG. Genomics of wood-degrading fungi. Fungal Genet. Biol. 2014; 72; 82-90.

48. Martinez D, Larrondo LF, Putnam N, Gelpke MD, Huang K, Chapman J, et al. Genome sequence of the lignocellulose degrading fungus Phanerochaete chrysosporium strain RP78. Nat. Biotechnol. 2004; 22; 695-700.

49. Van Kan JAL. Licenced to kill: the lifestyle of a necrotrophic plant pathogen Trends Plant Sci 2006; 11; 247-253.

50. Eastwood DC, Floudas D, Binder M, Majcherczyk A, Schneider P, et al. The plant cell wall-decomposing machinery underlies the functional diversity of forest fungi. Science 2011; 333; 762-765.

51. Vincent D, Kohler A, Claverol S, Solier E, Joets J, Gibson J, et al. Secretome of the free-living mycelium from the ectomycorrhizal basidiomycete Laccaria bicolor. J. Proteome Res. 2012; 11; 157-171.
52. Shawky BT, Mahmoud MG, Ghazy EA, Asker MM, Ibrahim GS. Enzymatic hydrolysis of rice straw and corn stalks for monosugars production. Journal of Genetic Engineering and Biotechnology. 2011; 9: 59-63.

53. Wi SG, Choi IS, Kim KH, Kim HM, Bae HJ. Bioethanol production from rice straw by popping pretreatment. Biotechnology for biofuels. 2013; 6: 166

54. Cuiping L, Chuangzhi W, Haitao $\mathrm{H}$. Chemical elemental characteristics of biomass fuels in China. Biomass and bioenergy. 2004; 27: 119-130.

55. Ming-Zhu $P$, Chang-Tong M, Xu-Bing Z, Yun-Lei $P$. Effects of rice straw fiber morphology and content on the mechanical and thermal properties of rice straw fiber-high density polyethylene composites. Journal of Applied Polymer Science. 2011; 12: 2900-2907.

56. Boonmee A. Hydrolysis of various thai agricultural biomasses using the crude enzyme from Aspergillus aculeatusiizuka FR60 isolated from soil. Brazilian Journal of Microbiology. 2012; 43; 456-466.

57. Zaid AA, Ganiyat O. Comparative utilization of biodegraded and undegraded rice husk in Clariasgariepinus diet. African journal of Biotechnology. 2009; 8: 1358-1362.

58. Bledzki AK, Mamun AA, Bonnia NN, Ahmad S. Basic properties of grain byproducts and their viability in polypropylene composites. Industrial Crops and Products. 2012; 37: 427-434.

59. Adapa P, Tabil L, Schoenau G. Compaction characteristics of barley, canola oat and wheat straw. Biosystems engineering. 2009; 104: 335-344.

60. Navarro D, Couturier M, da Silva GG, Berrin JG, Rouau X, Asther M, et al Automated assay for screening the enzymatic release of reducing sugars from micronized biomass. Microbial cell factories. 2010; 9: 58.

61. Hodgson EM, Nowakowski DJ, Shield I, Riche A, Bridgwater AV, CliftonBrown JC, et al. Variation in Miscanthus chemical composition and implications for conversion by pyrolysis and thermo-chemical bio-refining for fuels and chemicals. Bioresource technology. 2011; 102: 3411-3418.

62. Podkówka Z, Podkówka L. Chemical composition and quality of sweet sorghum and maize silages. Journal of Central European Agriculture. 2011; 12.

63. Serna-Saldívar SO, Chuck-Hernández C, Heredia-Olea E, Pérez-Carrillo E. Sorghum as a multifunctional crop for the production of fuel ethanol: Current status and future trends. INTECH Open Access Publisher; 2012.

64. Lesage-Meessen L, Bou M, Sigoillot J-C, Faulds CB, Lomascolo A. Essential oils and distilled straws of lavender and lavandin: a review of current use and potential application in white biotechnology. Appl. Microbiol. Biotechnol. 2015; 99; 3375-3385
J Bacteriol Mycol - Volume 4 Issue 2 - 2017

ISSN : 2471-0172 | www.austinpublishinggroup.com

Faulds et al. (C) All rights are reserved
Citation: Wikee S, Chumnunti P, Kanghae A, Chukeatirote E, Lumyong S and Faulds CB. Lignocellulolytic Capability of Endophytic Phyllosticta sp.. J Bacteriol Mycol. 2017; 4(2): 1047. 